Review

연잎 모사 구조로의 초소수성 표면 처리와 의료분야의 적용에 관한 연구

\author{
임진익* · 김승일* · 정영미* · 김수현 ***,† \\ *한국과학기술연구원 의공학연구소 생체재료 연구단, **고려대학교 한국과학기술연구원 융합대학원 \\ (2013년 5월 3일 접수, 2013년 5월 22일 수정, 2013년 5월 23일 채택)
}

\title{
Fabrication and Medical Applications of Lotus-leaf-like Structured Superhydrophobic Surfaces
}

\author{
Jin Ik Lim*, Seung Il Kim*, Youngmee Jung*, and Soo Hyun Kim*,**,† \\ *Division of Life and Health Sciences, Biomaterials Research Center, Korea Institute of Science and Technology, Seoul 136-791, Korea \\ **KU-KIST Graduate School of Converging Science and Technology, Korea University, Seoul 136-701, Korea
}

(Received May 3, 2013; Revised May 22, 2013; Accepted May 23, 2013)

\begin{abstract}
초록: 다양한 생체재료들이 이식용 인공장기나 의료용 장비로 폭넓게 사용되고 있으나 혈액과 접촉하는 경우가 많 아짐으로써 발생되는 혈전의 문제로 인해 이식재와 혈액간의 혈액 친화성의 향상이 연구자들에게 관심의 대상이 되 고 있다. 연잎의 표면구조는 항 오염 특성이라는 측면에서 많은 연구가 진행되어 왔으며, 산업적인 용도로 적용하고 자 하는 주된 시도들이 있어 왔다. 대부분 주형법이나 졸-젤 방법, 층 쌓기 방법 등을 포함한 다양한 기법으로 표면 처리를 함으로써 인위적인 모사가 가능해 왔다. 최근에 들어 이러한 표면의 초소수성 성질이 의료용 재료의 표면처 리 기법으로써 혈관 이식재에서부터 항 박테리아용 표면에까지 널리 적용하려는 시도가 진행되고 있다. 본 리뷰논 문에서는 최근 많이 사용되는 연잎 구조로의 표면처리 기법들을 중심으로 요약하였으며, 이들을 이용한 의료분야로 의 적용 시도들을 정리하고자 하였다.
\end{abstract}

\begin{abstract}
Various biomaterials have been widely used for biomedical applications, including bio-organs, medical devices, and clinical devices like vessel, blood pumps, artificial kidneys and hearts, even in contact with blood. The issue of blood compatibility has been studied intensively to prevent negative effects such as thrombosis due to the implanted devices. The use of lotus-leaf-like structured surfaces has been extended to an increasing number of applications such as contamination prevention and anticorrosion applications. Various methods such as template, sol-gel transition, layer-bylayer, and other methods, developed for the fabrication of lotus-leaf-like surfaces have been reported for major industrial applications. Recently, the non-wettable character of these surfaces has been shown to be useful for biomedical applications ranging from blood-vessel replacement to antibacterial surface treatment. In this review, we provide a summary of current and future research efforts and opportunities in the development and medical applications of lotus-leaf-like structure surfaces.
\end{abstract}

Keywords: lotus-leaf-like structure, superhydrophobic surface, medical application, biopolymer, blood compatible surface.

\section{Introduction}

Biopolymers have many industrial and research applications, including tissue engineering, gene therapy, novel drug-delivery systems, implantable devices, and nanotechnology. Medical polymers of these types include poly(lactic acid), poly(glycolic acid), poly(lactide-co-glycolide), poly( $\varepsilon$-caprolactone), poly(glycolide-co-caprolactone), poly(L-lactide-co- $\varepsilon$-caprolactone), poly-

${ }^{\dagger}$ To whom correspondence should be addressed.

E-mail: soohkim@kist.re.kr styrene, polypropylene, polyurethane, and silicone. Biopolymers are desired for blood-contact applications such as tissue-engineered blood vessels and polymer stents. ${ }^{1-4}$ Unfortunately, these polymers have been found to give rise to adverse effects such as blood clots and tissue capsulation by interface reaction between artificial surface and biomolecules. 5,6

Especially, the interaction of blood with biopolymers as foreign materials is very complicated. The adsorption of plasma proteins is the first event that occurs on the biopolymer surfaces when they come into contact with blood, and platelet adhesion that follows contributes to surface-induced throm- 
bosis. If the adsorbed protein is denatured, the coagulation factors are activated; this causes a series of cascade reactions leading to blood coagulation. ${ }^{7-9}$ Blood-biopolymer interactions are multistep, interlinked processes to which much research attention has been devoted. ${ }^{7-14}$ The main events occurring within minutes of contact between biopolymer surfaces and blood are protein adsorption, cell adhesion, and inflammation, which lead to thrombus formation and fibrinolysis. Longer exposure of a biopolymer to blood could lead to embolization, calcification, and changes in the biopolymer properties. These interactions have a significant effect on the short-term and long-term thrombotic responses induced by the materials. ${ }^{8}$

Various approaches have been adopted to improve the blood compatibility of polymeric materials. ${ }^{15-17}$ These include endothelial cell culture or immobilization, ${ }^{18}$ chemical modification including drugs, ${ }^{19-21}$ and the use of biological anticoagulants such as heparin, prostaglandin, and urokinase.

Unfortunately, these techniques do not solve the problem of low drug loadings and the lack of extended release periods, and thrombus formation remains a serious problem in the use of biopolymers. Therefore, the control of interfacial properties through physical modification rather than chemical modification of the biopolymer surfaces is desirable, as a novel method is required to improve the blood compatibility of these materials.

The superhydrophobic effect is well known in nature and is due to the entrapment of air within surface asperities beneath the contacting wetting fluid (Figure 1). Trapped air greatly enhances net water repellency and is thus termed superhydrophobicity. ${ }^{22}$ Water repellency of lotus leaves and bird feathers are commonly-cited examples. ${ }^{23,24}$ Superhydrophobic surfaces for various functional applications, including biosurface, anti-biofouling, transparent, and antireflective superhydrophobic coatings, structural coloring, fluidic drag reduction, enhancement of water-supporting force, controlled trans-

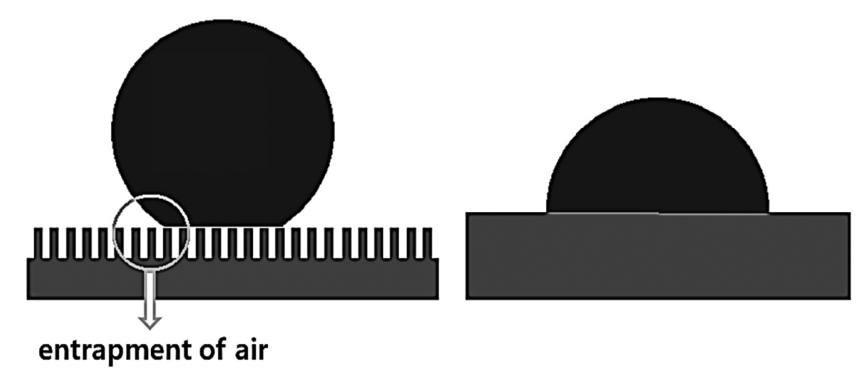

Figure 1. Wetting states (L: superhydrophobic surface, R: untreated surface). portation of fluids, superhydrophobic valves, battery and fuelcell applications, and prevention of water corrosion and oilwater separation have been investigated by many research groups. ${ }^{25}$ Superhydrophobic and superhydrophilic effects are of technical interest in many biomaterial applications including cardiovascular biomedical devices; such as in development of advanced vascular grafts and heart valves. ${ }^{26}$ Here, the role of trapped air in superhydrophobic surfaces is thought to control resistance to protein adsorption, ${ }^{27}$ adhesion of platelets, ${ }^{26}$ and cells. ${ }^{28}$ Recently, the non-wettable property of superhydrophobic surfaces has been reported for biomedical applications ranging from blood-vessel replacement to wound management. ${ }^{29}$ Furthermore, the antithrombotic effects of the superhydrophobic surfaces of lotus-leaf-like structured biopolymers have already been reported by many researchers. ${ }^{29}$ Various methods such as template tool, sol-gel transition, solution evaporation, layer-bylayer self-assembly, and electrospinning techniques have been reported for the fabrication of superhydrophobic surfaces for medical applications. ${ }^{30-38}$

In this review, we attempt to provide a concise discussion of the most recent advances in the area of the superhydrophobicity of biopolymer surfaces; this includes popular strategies for the fabrication of lotus-leaf-inspired rough surfaces, and methods for the surface modification of biopolymer surfaces for applications in medical fields.

\section{Fabrication of Lotus-leaf-like Structured Superhydrophobic Surfaces}

Etching and Lithography. Etching is a straightforward and effective way of fabricating rough surfaces. Different etching methods, including plasma etching, ${ }^{39}$ laser etching, ${ }^{40}$ and chemical etching, ${ }^{41}$ have been used in the past year for the fabrication of superhydrophobic surfaces. As a fast surface treatment method, etching is usually applied to metals or inorganic materials. The lithographic process is a well-established technique, and its subtechniques used for making superhydrophobic surfaces include optical lithography (photolithography), ${ }^{42-44}$ soft lithography, ${ }^{45}$ nanoimprint lithography, ${ }^{46}$ electron-beam lithography, ${ }^{47} \mathrm{X}$-ray lithography, ${ }^{48}$ and colloidal lithography. ${ }^{49}$ As shown in Figure 2, various uniform nano- and microstructured superhydrophobic surfaces have been fabricated through etching and lithography methods. ${ }^{40,41,44}$ However, these methods are usually used to inorganic surfaces including metal, ceramic compound. For application to various polymers, more research is needed. 

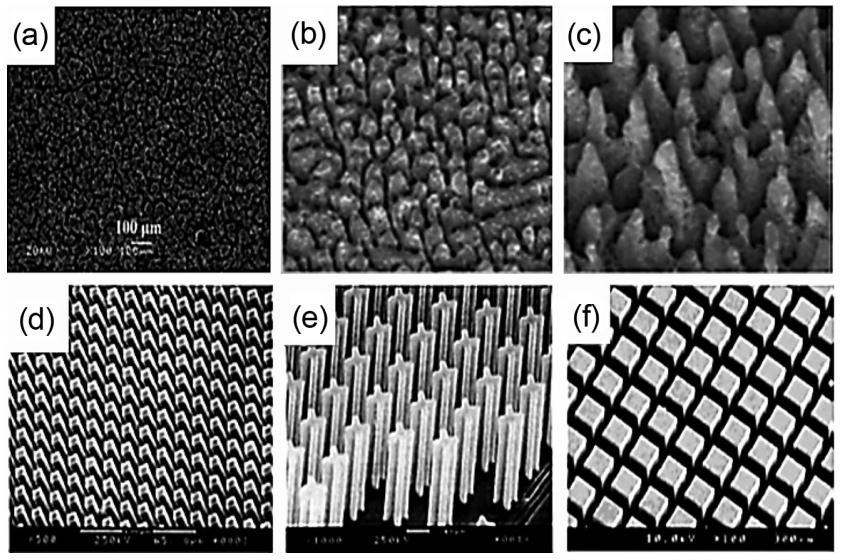

Figure 2. Surface modification by etching [(a) roughened aluminium alloy; ${ }^{41}$ (b) laser-etched silicon surface in $\mathrm{SF}_{6} 3.2 \mathrm{kJm}^{-2}$; (c) using $\left.5 \mathrm{kJm}^{-2}{ }^{40}\right]$ and lithographic surface modification [(d) photolithographic towers; (e) indented square posts; ${ }^{43}$ (f) diced silicon wafer $^{44}$. Reproduced with permission form ref.40,41,43,44.

Templating. A pattern or shape, either 2D or 3D, can be replicated using a templating method, wherein a material is printed, pressed, or grown against the voids of a template. Often, the template is subsequently removed, leaving the inverse of its pattern; this can then be used as a template to achieve a replica of the original. ${ }^{50}$

The templating method for surfaces is generally a fast, very low-cost, and reproducible technique, and is therefore used widely for the preparation of polymeric surfaces. Any surface can be used as a template, such as colloidal, lithographic, and woven material surfaces; some of these masters may be reused, and some may be destroyed intentionally to reveal the replica surface. In the general case, aluminum oxide layers can be grown on aluminum metal under anodic potentials in acid. ${ }^{51}$ The oxide forms nanopores in a hexagonal array, with sizes determined by the potential used. The porous arrays have been used for the templating of aligned nanocolumns of various materials, including carbon, polymers, and metals. ${ }^{51}$ However, for removal of anodized aluminum oxide template, dissolution time over $1 \mathrm{hr}$ in strong alkali solution is required. Therefore, we supposed that change of physicochemical properties is caused by hydrolysis of biodegradable polymer. Recently, as nondegradable biopolymer, superhydrophobic polytetrafluoroethylene (Teflon, DuPont), sub-micro and nanostructures were fabricated by the dipping and templating method, based on anodization process in oxalic acid. Polytetrafluoroethylene nanotubes formed in this way have been shown to exhibit high water-contact angles $\left(>150^{\circ}\right)$ (Figure 3). ${ }^{51-53}$

Layer-by-Layer (LbL) and Colloidal Assembly. The layer-
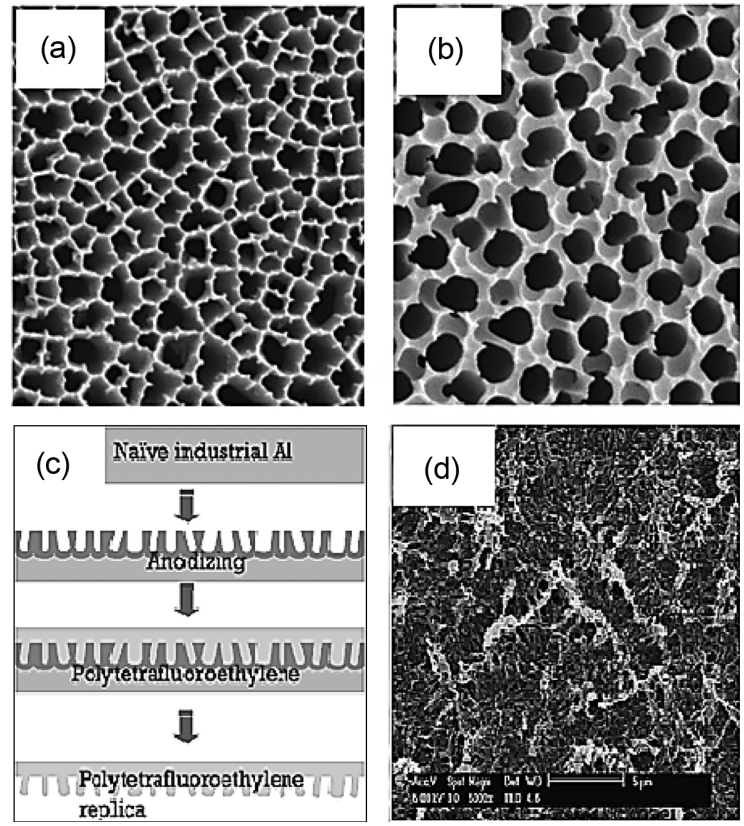

Figure 3. (a) SEM image of surface of commercial porous aluminum oxide (PAO, Anopore), with pores ranging from 200 to $40 \mathrm{~nm}$ in diameter ${ }^{51}$; (b) reverse of panels (a) with pore diameters from 100 to $200 \mathrm{~nm}^{51}$; (c) overall process scheme for superhydrophobic polytetrafluoroethylene replica structures ${ }^{53}$; (d) field-emission SEM surface images of the superhydrophobic replica. ${ }^{53}$ Reproduced with permission form ref.51,53.

by-layer (LbL) technique introduced by Decher et al..$^{54,55}$ holds great potential for the fabrication of superhydrophobic coatings for practical applications because of its simplicity, versatility, and independence of the morphology and size of the substrate used in the assembly process. Recently, the LbL process has been used by several groups to make rough superhydrophobic surfaces. ${ }^{56,57}$ For example, Zheng et al. ${ }^{58}$ used an LbL technique to create a poly(vinylpyrrolidone)/poly(urushiol)-CuS multilayer, which formed a stable lychee-like structure on the surface after appropriate combination of (PVP/PU-Cu $)_{n}$ coatings on a $(\mathrm{PVP} / \mathrm{U})_{3}$ film (Figure 4). Among the various methodologies for creating superhydrophobic coatings with hierarchical structures, bottom-up colloidal self-assembly is a simple, fast, and inexpensive technique..$^{59,60}$ The micro- and nanoscale structures can be controlled precisely by choosing monodispersed particles with well-defined sizes. Air, which is the most hydrophobic material, is trapped in the interstitial sites of the assembled micro/nanoparticles, increasing the contact angles significantly. ${ }^{61}$ The hydrophobicity can be improved further through functionalization of the colloidal particle surfaces.

Sol-Gel Process. In general, the sol-gel process involves the transition of a system from a liquid "sol" (mostly colloidal) 

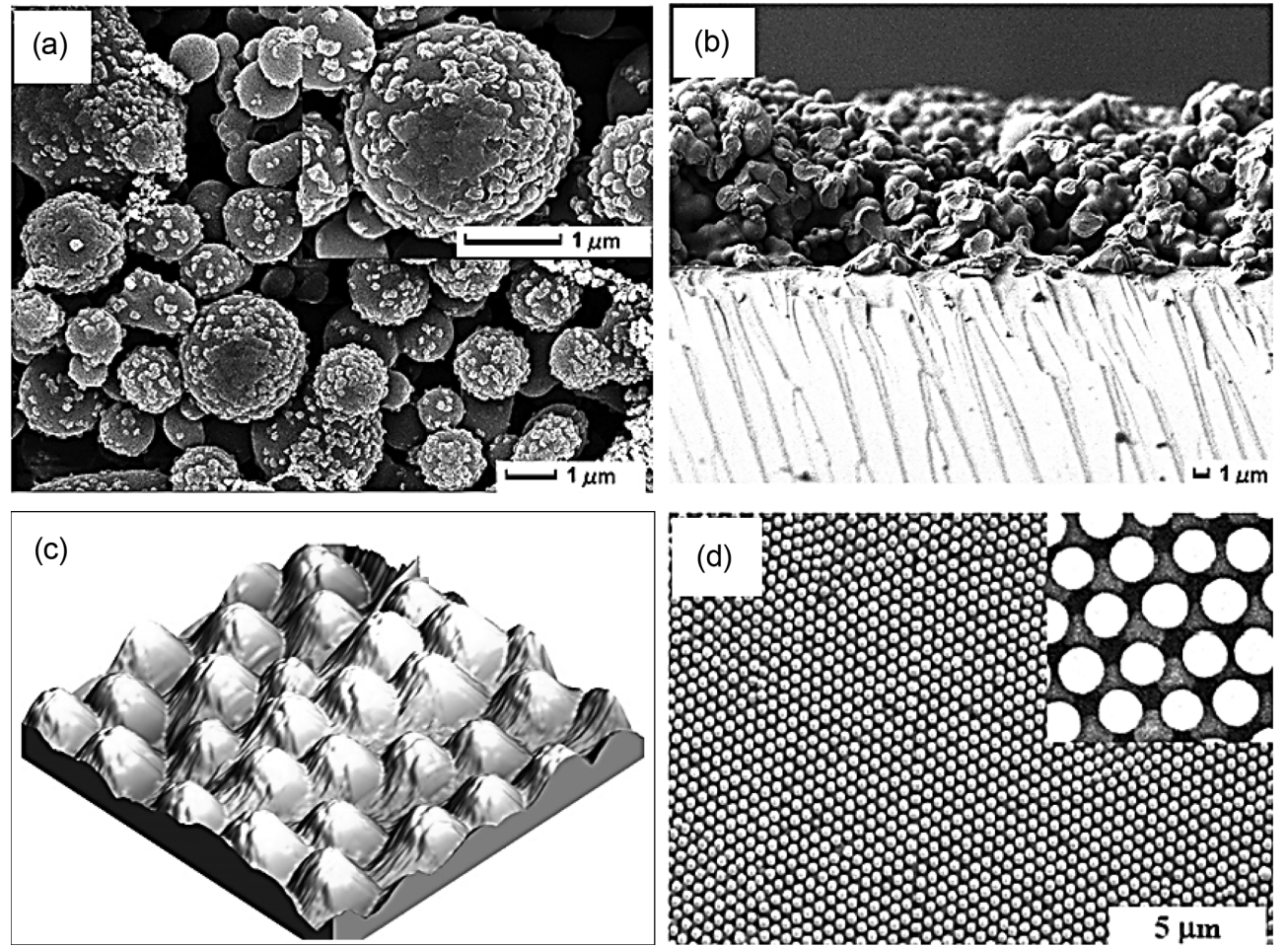

Figure 4. Superhydrophobic surface by layer-by-layer (LbL) (a) SEM images of the superhydrophobic (poly 2-vinylpyridine/polyurethane$\mathrm{CuS})_{8}$ film. Inset: magnified view of PU-CuS particles in a) ${ }^{58}$; (b) the cross-sectional SEM image of the superhydrophobic (poly 2-vinylpyridine/polyurethane-CuS $)_{8}$ film $^{58}$; superhydrophobic surface by colloidal assembly; (c) AFM image of colloidal assembly ${ }^{61}$; (d) top-view SEM image of a double layer crystal. Inset shows a magnified SEM image. ${ }^{61}$ Reproduced with permission form ref.58,61.

into a semi-solid "gel" phase. The sol-gel methods have been utilized to create superhydrophobic surfaces in accordance with Wenzel or Cassie-Baxter's theories since the very early stage of mimicking lotus leaves' surface structure. ${ }^{62-64}$ It involves a chemical solution deposition, during which the chemical solution or sol is utilized as a precursor on the selected substrate to form a gel-like network. The dip coating method is a novel and facile route for the synthesis of transparent and uniform films by the sol-gel process. The sol-gel technique with simple dip coating method is used to prepare silica films on glass substrates. ${ }^{65}$ Tadanaga et al ${ }^{66}$ reported the formation of transparent superhydrophobic films on glass plates through the sol-gel method by the combination of microstructural and chemical approaches. The surface chemical modification of silica films using trimethylchlorosilane as a silylating agent has been reported. ${ }^{67}$ However, the method is usually used to surface treatment using an inorganic or organic-inorganic compound including silica and silicone. Surface modification with hydrophobic properties using the solgel method has been investigated during the recent years.

Electrospinning and Electrospraying. Developments in nanoscience and nanotechnology have led to the fabrication of various nanostructures such as nanoparticles, nanofibers, nanowires, nanotubes, and nanobelts. Among nanofabrication techniques, electrospinning and electrospraying have been identified as remarkably robust and versatile methods for the fabrication of lotus-leaf-like surface structures.$^{68} \mathrm{~A}$ variety of materials such as polymers, ceramics, and even metals have been electrospun into uniform fibers or spheres with well-controlled sizes, compositions, and morphologies. ${ }^{68,69}$ Electrospinning is a simple and versatile method for the production of continuous polymer fibers on the micro- or nanoscale. ${ }^{70}$ It is an effective way to create superhydrophobic surfaces under strong electric field. ${ }^{71}$ For the formation of uniform fibers, the molecular weight of the polymer and the concentration of the solution should be properly controlled. ${ }^{72}$ On the other hand, the electrospraying technique is not necessarily restricted to fibers. Polymer films deposited by electrospraying can range from spheres to fibers. ${ }^{73}$ However, it is generally considered that fibers are produced during the electrospinning process, whereas beads are produced during the electrospraying process. $^{74}$ As shown in Figure 5, various lotus-leaf-like structures 

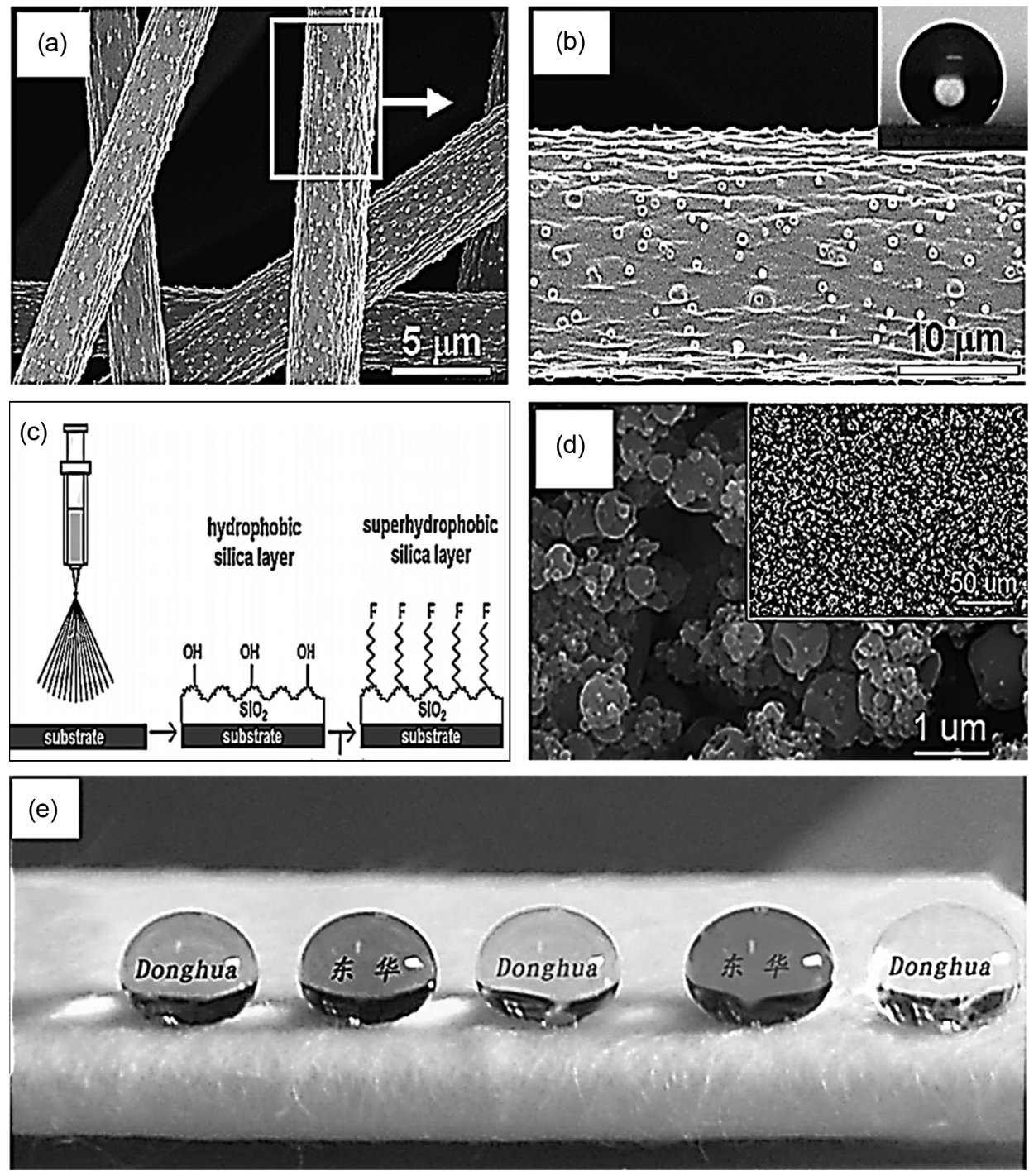

Figure 5. (a), (b) SEM images of electrospun polystyrene fibers from $35 \mathrm{wt} \%$ solution in dimethyl formamide, water droplet on electrospun polystyrene fibers in (b) ${ }^{71}$; (c) illustration conceptually showing the steps used to synthesize superhydrophobic rough, fluorinated $\mathrm{SiO}_{2}$ layers by electrospray ${ }^{73}$; (d) surface microstructure of synthesized superhydrophobic rough, fluorinated $\mathrm{SiO}_{2}$ layers by electrospary, observed by $\mathrm{SEM}^{72}$; (e) several water droplets placed on the composite polystyrene/polyamide 6 fibrous membranes. ${ }^{72}$ Reproduced with permission form ref.71-73.

have been fabricated using electrospinning and electrospraying methods.

\section{Applications of Lotus-leaf-like Structures in Medical Fields}

Blood-compatible Surface. When a biomaterial surface comes into contact with fresh blood, the blood proteins will be adsorbed onto it rapidly; this adsorption is followed by activities such as clotting factors activation or platelet adhesion and activation. Finally, thrombus formation occurs on artificial bio- material surfaces. Because this is a surface reaction, any reduction in the effective contact area between the blood and the implanted surface tends to suppress blood clotting. Therefore, the non-wettable character of a superhydrophobic surface with geometrical roughness is attractive for antithrombosis materials. ${ }^{75}$ Recently, the antithrombosis effects of lotus-leaf-like surfaces have been reported by various researchers. Zhou et al. found a novel strategy for the significant improvement of the blood compatibility of nanostructured trichloro $(1 \mathrm{H}, 1 \mathrm{H}, 2 \mathrm{H}, 2 \mathrm{H}-$ perfluorooctyl)silane on silicone (Figure 6) ${ }^{76}$ Mao et al. reported the enhanced blood compatibility of micro- and nano- 

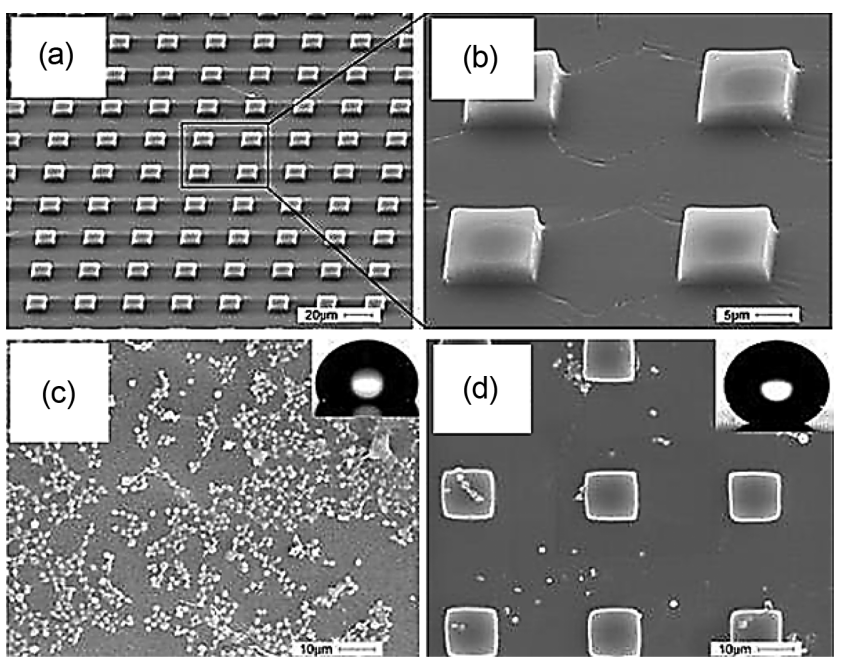

Figure 6. (a); (b) SEM image of arrays of pillar structures made of polydimethylsiloxane, SEM of platelets adhesion to (c) a flat substrate; (d) the surfaces with micro-pillars (width $a=10 \mu \mathrm{m}$, height $h=5 \mu \mathrm{m}$; spacing $b=25,35$, and $45 \mu \mathrm{m}$ respectively. ${ }^{76}$ Reproduced with permission form ref.76.
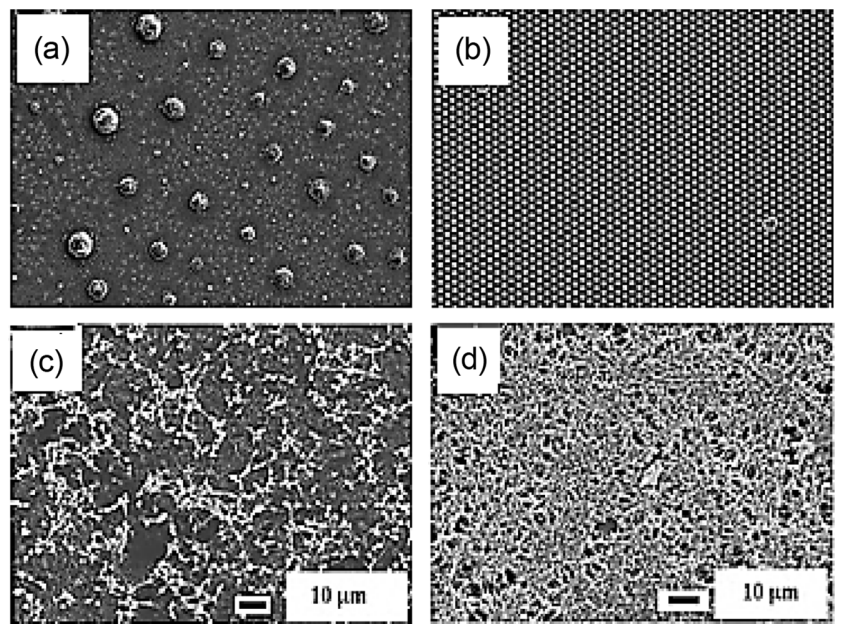

Figure 7. SEM images of the agglomerated platelets after fixation onto (a) a flat poly-Si surface; (b) the superhydrophobic surface of the fabricated poly-Si nanoshell array, SEM images of original polypropylene surfaces exposed to (c) platelet-rich plasma solution for $90 \mathrm{~min}$, and SEM images of polypropylene superhydrophobic surfaces exposed to (d) platelet-rich plasma solution for $90 \mathrm{~min}^{78}$ Reproduced with permission form ref.78.

structures of lotus-leaf-like structured polystyrene films. The films were fabricated by solvent-casting-template and melttemplate (M-PS) methods, and the lower thrombus formation of the lotus-leaf-like structure compared with the untreated film was confirmed. ${ }^{53}$ Furthermore, cylindrical nanoshell arrays were fabricated to reduce the contact area between the blood and the implanted surface, and enhanced antithrombosis effects were confirmed through platelet-rich plasma tests. ${ }^{53,77}$ Hou et al. ${ }^{78}$ reported the PP superhydrophobic surface and its blood compatibility. The method used for the fabrication of the PP superhydrophobic surface is simple and reproducible: a few drops of the polymer solution $(20 \mathrm{mg} / \mathrm{mL}, 60 \%$ p-xylene $/ 40 \%$ methyl ethyl ketone mixture by volume) were dropped onto glass slides, and the solvent was evaporated at $25^{\circ} \mathrm{C}$ in a vacuum oven (Figure 7). Recently, progress has been made in this area, and an optimal surface modification method for bloodcompatible biopolymer surfaces has been validated.

Artificial Heart-valve Surface. Artificial heart valves that are clinically used are classified as bioprosthetic valves and mechanical valves. The biocompatibility and antithrombosis property of the bioprosthetic valve are quite good, but its durability remains a problem because it is easily calcified and torn. The average lifetime of a bioprosthetic valve is only 5-8 years. ${ }^{79}$ So far, no effective way has been found to improve its durability. In contrast, the main part of a mechanical valve is made of nonbiological material such as titanium alloy, stainless steel, low-temperature isotropic carbon, and polyurethane ${ }^{80}$; therefore, this type of valve has a relatively long durability of up to 30-50 years. However, the mechanical valve has poor blood compatibility. Nano- and microstructured superhydrophobic surfaces for heart valves are under investigation, with the aim of decreasing the risk of thrombosis complications and calcifications. To mimic the microstructure on the surface of a natural rabbit heart valve, Ye et al..$^{81}$ studied the hierarchical
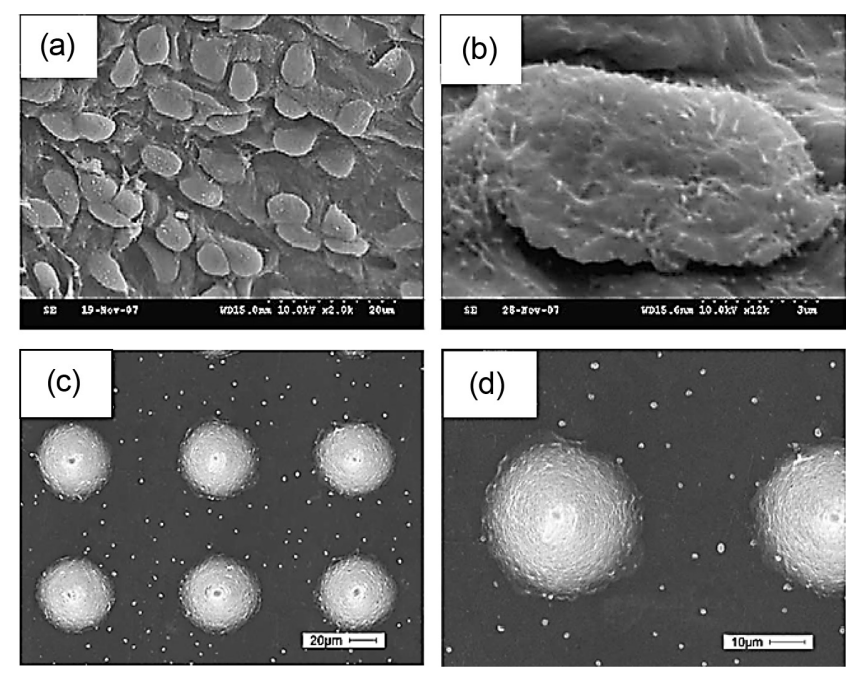

Figure 8. The heart valve of rabbit: (a) large-scale SEM image of the micro-structure of valve surface; (b) magnified image on a single cobblestone of (a); platelets adhesion on the mastoid microstructure polydimethylsiloxane surface; (c) low magnification; (d) high magnification. ${ }^{81}$ Reproduced with permission form ref.81. 
structure on a polydimethylsiloxane surface by using a femtosecond laser fabrication technique and soft lithography technology. As a result of this study, an enhanced antithrombosis effect and more natural heart-valve surface was obtained (Figure 8). Therefore, lotus-leaf-like structured surfaces could be applied for the optimal surface treatment of various blood-contact medical devices.

Antibacterial Surface for Medical Device Applications. The prevention of bacterial adherence to surfaces is of the utmost importance in many industries, and especially in healthcare and medical devices. ${ }^{82}$ Medical biopolymers such as silicone, polyurethane, PP, polystyrene, and various biodegradable polymers are often used in medical devices (heart valves, suture materials, syringes or dialysis systems, etc.). With regard to this recent social issue, there has been great progress in the development of new strategies to reduce the bacterial contamination of these polymeric surfaces. Recent developments in the area of surface-acquired infection prevention include surfaces with antimicrobial compositions ${ }^{83}$ and surfaces that facilitate the irradiative killing of bacteria. ${ }^{84}$ These surfaces are aimed to kill any bacteria on the surface; this could, however, leave a film of dead bacteria on the surface, which would inhibit further killing while providing a favorable platform for subsequent bacterial attachment. ${ }^{85}$ Superhydrophobic synthetic surfaces were first demonstrated in the mid$1990 \mathrm{~s},{ }^{25,29,30}$ which have still not been explored in detail in the field of antibacterial surfaces. As shown in Figure 9, several studies have shown the positive effects of these new surfaces on pathogenic bacterial adsorption, ${ }^{86,87}$ cell-and-protein interaction and adhesion, ${ }^{88}$ and bacterial adhesion on elastomeric superhydrophobic surfaces. ${ }^{89}$

\section{Conclusions and Outlook}

Bio-inspired special wettability is a promising field in materials science and surface science. Since the first reports on superhydrophobic materials in the mid-1990s, ${ }^{25,29,30}$ many different synthetic strategies have been developed for the construction of superhydrophobic materials, and various applications have been demonstrated in the fields of optics, sensors, biomedicine, marine engineering, self-cleaning, microdevices, etc. Therefore, the number and scope of techniques for the generation of lotus-leaf-like structured superhydrophobic surfaces has increased greatly in recent years,

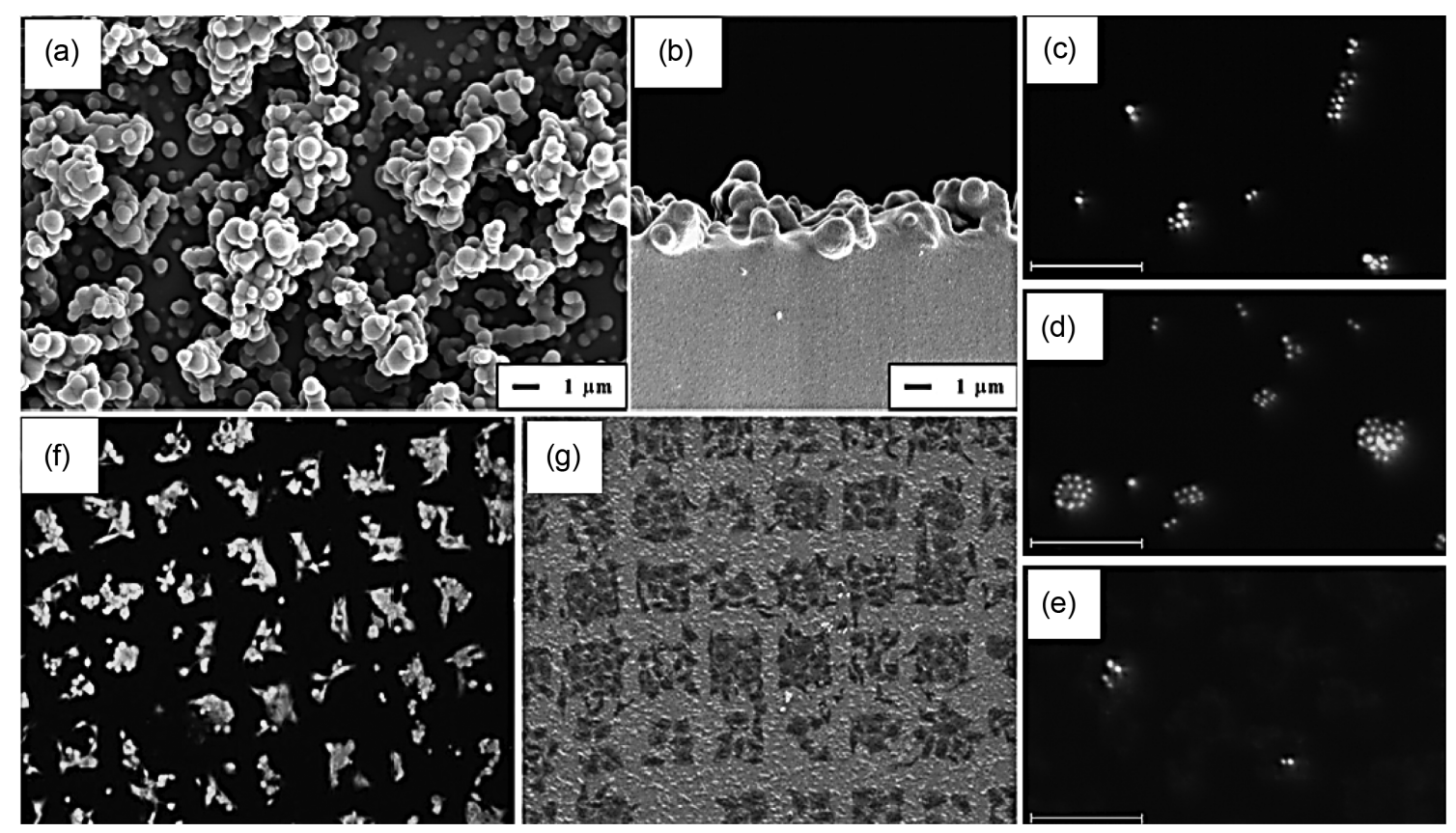

Figure 9. SEM images of a Sylgard ${ }^{\circledast} 184$ film deposited using aerosol assisted chemical vapour deposition (AACVD) using a deposition temperature of $360{ }^{\circ} \mathrm{C}$ onto a glass microscope slide pre-treated with a dip-coated layer of the same elastomer; (a) from above (b) side-on ${ }^{89}$; fluorescence microscopy of $S$. Aureus attached to glass surfaces. Images are of a section of a microscope field of view showing live (green) and dead (red) S. Aureus cells attached to (c) uncoated glass; (d) dip-coated glass; (e) AACVD coated glass after 1 hr exposure to identically populated bacterial suspensions. Bar represents $10 \mu \mathrm{m}^{89}$; (f) fluorescence microscopy images of Calcein-AM stained hFOB 1.19 cells attached to superhydrophobic/superhydrophilic microtemplates ${ }^{88}$; (g) SEM images of HeLa cells attached to superhydrophobic/superhydrophilic microtemplates from fetal bovine serum solutions ${ }^{88}$ Reproduced with permission form ref.88,89. 
with the concomitant expansion of their suggested applications. Above all, a fundamental requirement for superhydrophobic surfaces, especially for medical applications, is an optimal method for the surface modification of various biopolymers. Fundamental investigations are still necessary for the design of versatile medical biopolymers. This review has provided a comprehensive description of the design and fabrication of bio-inspired superhydrophobic smart surfaces as modified surfaces for medical applications. This combination of biomaterials science and nanotechnology will lead to innovations in the preparation of new biomaterials and their novel applications.

Acknowledgment: This work was supported by the National Research Foundation of Korea Grant funded by the Korean Government (MEST)" NRF-2010-C1AAA001-20100028939.

\section{References}

1. C. M. Agrawal, K. F. Haas, D. A. Leopold, and H. G. Clark, Biomaterials, 13, 176 (1992).

2. K. M. Sedlarik, P. B. van Wachem, H. Bartels, and J. M. Schakenraad, Biomaterials, 11, 4 (1990).

3. J. C. A. Palmaz, J. Roentgenol., 160, 613 (1993).

4. K. T. Kurpinski, J. T. Stephenson, R. R. R. Janairo, H. Lee, and S. Li, Biomaterials, 31, 3536 (2010).

5. H. Shen, X. X. Hu, F. Yang, J. Z. Bei, and S. G. Wang, Biomaterials, 28, 4219 (2007).

6. H. Shen, X. X. Hu, F. Yang, J. Z. Bei, and S. G. Wang, Acta Biomater., 6, 455 (2010).

7. Y. P. Yiann, in Structural and Dynamic Properties of Lipids and Membranes, P. J. Quinn, and R. Cherry, Editors, Portland Press, London, UK, p187 (1992).

8. C. D. Forbes, and J. M. Courtney, Scot. Med. J., 40, 99 (1995).

9. J. M. Courtney and C. D. Forbes, Brit. Med. Bull., 50, 966 (1994).

10. S. Sundaram, H. Q. Yin, and C. D. Forbes, Vasc. Med. Rev, 5, 42 (1994).

11. J. M. Courtney, N. M. K. Lamba, S. Sundaram, and C. D. Forbes, Biomaterials, 15, 737 (1994).

12. T. A. Horbett, Cardiovasc. Pathol., 2, 137 (1993).

13. J. L. Brash and T. A. Horbett, Proteins at Interfaces II, J. L. Brash, and T. A. Horbett, Editors, ACS Symposium Series, American Chemical Society, Washington, DC, USA, Vol 602, $p$ 1 (1995)

14. W. B. Tsai, J. M. Grunkemeier, and T. A. Horbett, J. Biomed. Mater. Res., 44, 130 (1999).

15. J. D. Andrade, S. Nagaoka, S. L. Cooper, T. Okano, and S. W. Kim, ASAIO J., 10, 75 (1987).

16. K. Ishihara, T. Tsuruta, T. Hayashi, K. Kataoka, K. Ishihara, and
Y. Kimura, Editors, in Biomedical Applications of Polymeric Materials, CRC Press, Boca Raton, FL, p 89 (1993).

17. B. D. Ratner, J. Biomater. Sci. Polym. Ed., 11, 1107 (2000).

18. R. Langer and J. P. Vacanti, Science, 260, 920 (1993).

19. Y. H. Kim, K. D. Park, and D. K. Han, in Polymeric Materials Encyclopedia, J. C Salamone, Editor, CRC Press, Boca Raton, FL, p 825 (1996).

20. S. W. Kim and J. Feijen, CRC Crit. ReV. Biocompat., 1, 229 (1985).

21. P. Olsson, J. Sanchez, T. E. Mollnes, and J. J. Riesenfeld, J. Biomater. Sci. Polym. Ed., 11, 1261 (2000).

22. L. Gao and T. J. McCarthy, Langmuir, 25, 1410 (2009).

23. C. R. Crick and I. P. Parkin, Chem.-Eur. J., 16, 3568 (2010).

24. W. L. Song, D. D. Veiga, C. A. Custodio, and J. F. Mano, $A d v$. Mater., 21, 1830 (2009).

25. X. Zhang, F. Shi, J. Niu, Y. Jiang, and Z. Wang, J. Mater. Chem., 18, 621 (2008).

26. J. I. Lim, S. I. Kim, and S. H. Kim, Colloid. Surf. B: Biointerfaces, 103, 463 (2013)

27. E. S. Leibner, N. Barnthip, W. Chen, C. R. Baumrucker, J. V. Badding, M. Pishko, and E. A. Vogler, Acta Biomater., 5, 1389 (2009).

28. Y. L. Wang, C. E. Sims, P. Marc, M. Bachman, G. P. Li, and N. L. Allbritton, Langmuir, 22, 8257 (2006).

29. M. Ma and R. M. Hill, Curr. Opin. Colloid Interface Sci., 11, 193 (2006).

30. W. Lee, M. K. Jin, W. C. Yoo, and J. K. Lee, Langmuir, 20, 7665 (2004).

31. K. Acatay, E. Simsek, C. O. Yang, and Y. Z. Menceloglu, Angew. Chem. Int. Ed., 43, 5210 (2004).

32. Q. D. Xie, G. Q. Fan, N. Zhao, X. L. Guo, J. Xu, J. Y. Dong, L. Y. Zhang, Y. J. Zhang, and C. C. Han, Adv. Mater., 16, 1830 (2004).

33. N. Zhao, Q. D. Xie, L. H. Weng, S. Q. Wang, X. Y. Zhang, and J. Xu, Macromolecules, 38, 8996 (2005).

34. Z. Yoshimitsu, A. Nakajima, T. Watanabe, and K. Hashimoto, Langmuir, 18, 5818 (2002).

35. L. Jiang, Y. Zhao, and J. Zhai, Angew. Chem. Int. Ed., 43, 4338 (2004).

36. Y. Yao, X. Dong, S. Hong, H. Ge, and C. C. Han, Macromol. Rapid Commun., 27, 1627 (2006).

37. K. Tsujii, T. Yamamoto, T. Onda, and S. Shibuchi, Angew. Chem. Int. Ed. Engl., 36, 1011 (1997).

38. R. Buzio, C. Boragno, F. Biscarini, F. B. D. Mongeot, and U. Valbusa, Nat. Mater, 2, 233 (2003).

39. K. Teshima, H. Sugimura, Y. Inoue, O. Takai, and A. Takano, Appl. Surf. Sci., 244, 619 (2005).

40. T. Baldacchini, J. E. Carey, M. Zhou, and E. Mazur, Langmuir, 22, 4917 (2006).

41. Z. Guo, F. Zhou, J. Hao, and W. Liu, J. Colloid Interface Sci., 303, 298 (2006).

42. Y. Kwon, N. Patankar, J. Choi, and J. Lee, Langmuir, 25, 6129 (2009). 
43. D. Oner and T. J. McCarthy, Langmuir, 16, 7777 (2000).

44. Z. Yoshimitsu, A. Nakajima, T. Watanabe, and K. Hashimoto, Langmuir, 18, 5818 (2002).

45. Y. C. Jung and B. Bhushan, Langmuir, 25, 9208 (2009).

46. S. M. Lee and T. H. Kwon, J. Micromech. Microeng., 17, 687 (2007).

47. J. Z. Wang, Z. H. Zheng, H. W. Li, W. T. S. Huck, and H. Sirringhaus, Nat. Mater, 3, 171 (2004).

48. R. Furstner, W. Barthlott, C. Neinhuis, and P. Walzel, Langmuir, 21, 956 (2005).

49. X. M. Zhang, J. H. Zhang, Z. Y. Ren, X. Li, X. Zhang, D. Zhu, T. Wang, T. Tian, and B. Yang, Langmuir, 25, 7375 (2009).

50. P. Roach, N. J. Shirtcliffe, and M. I. Newton, Soft Matter, 4, 224 (2008).

51. C. J. Ingham, J. ter Maat, and W. M. de Vos, Biotechnol. Adv., 30, 1089 (2012).

52. D. Kim, W. Hwang, H. C. Park, and K. H. Lee, Curr. Appl. Phys., 8, 770 (2008).

53. C. Mao, C. Liang, W. Luo, J. Bao, J. Shen, X. Hou, and W. Zhao, J. Mater. Chem., 19, 9025 (2009).

54. G. Decher, J. D. Hong, and J. Schmitt, Thin Solid Films, 831, 210 (1992).

55. G. Decher, Science, 277, 1232 (1997).

56. F. Shi, Z. Q. Wang, and X. Zhang, Adv. Mater., 17, 1005 (2005).

57. N. Zhao, F. Shi, Z. Q. Wang, and X. Zhang, Langmuir, 21, 4713 (2005).

58. X. L. Zheng, J. B. Weng, B. H. Hu, X. Z. Lv, D. L. Meng, and A. S. C. Chan, Mater. Chem. Phys., 130, 1054 (2011).

59. Y. Zhao, M. Li, Q. H. Lu, and Z. Y. Shi, Langmuir, 24, 12651 (2008).

60. A. M. Brozell, M. A. Muha, A. Abed-Amoli, D. Bricarello, and A. N. Parikh, Nano Lett., 7, 3822 (2007).

61. H. Yang and P. Jiang, J. Colloid Interface Sci., 352, 558 (2010).

62. R. N. Wenzel, Ind. Eng. Chem., 28, 988 (1936).

63. A. B. D. Cassie and S. Baxter, Trans Faraday Soc., 40, 546 (1944).

64. Y. Y. Liu, X. Q. Chen, and J. H. Xin, Nanotechnology, 17, 3259 (2006).

65. H. M. Shang, Y. Wang, S. J. Limmer, T. P. Chou, K. Takahashi, and G. Z. Cao, Thin Solid Films, 472, 37 (2005).

66. K. Tadanaga, N. Katata, and T. Minami, J. Am. Ceram. Soc., 80, 1040 (1997).

67. J. Wang, C. R. Zhang, and J. Feng, Acta Physico-Chim., 20, 1399 (2004).

68. Q. Zhang and G. Cao, Nano Today, 6, 91 (2011).

69. Y. Dzenis, Science, 304, 1917 (2004).
70. M. L. Ma, R. M. Hill, J. L. Lowery, S. V. Fridrikh, and G. C. Rutledge, Langmuir, 21, 5549 (2005).

71. M. Kang, R. Jung, H. S. Kim, and H. J. Jin, Colloids and Surfaces A: Physicochem. Eng. Aspects, 313, 411 (2008).

72. X. Wang, B. Ding, J. Yu, and M. Wang, Nano Today, 6, 510 (2011).

73. E. K. Kim, C. S. Lee, and S. S. Kim, J. Colloid Interface Sci., 368, 599 (2012).

74. J. F. Zheng, A. H. He, J. X. Li, J. A. Xu, and C. C. Han, Polymer, 47, 7095 (2006)

75. A. J. Schrauth and N. P. Suh, "Axiomatic Design of Non-wetting Hemocompatible Surfaces", in Proceedings of 4th International Conference on Axiomatic Design, Firenze, Italy (2006).

76. M. Zhou, J. Yang, X. Ye, A. Zheng, G. Li, P. Yang, Y. Zhu, and L. Cai, J. Nano Res., 2, 129 (2008).

77. H. Im, Y. B. Park, J. Suk, M. Im, C. O. Joe, and Y. K. Choi, 14th International Conference on Miniaturized Systems for Chemistry and Life Sciences Groningen, The Netherlands, 3-7 October (2010).

78. X. Hou, X. Wang, Q. Zhu, J. Bao, C. Mao, L. Jiang, and J. Shen, Colloid. Surf. B: Biointerfaces, 80, 247 (2010).

79. M. M. Black, P. J. Drury, and W. B. Tindale, J. Royal Soc. Med., 76, 667 (1983).

80. D. Medart, U. Steinseifer, H. Reul, and T. Schmitz-Rode, J. Heart Valve Dis., 15, 710 (2006).

81. X. Ye, Y. Shao, M. Zhou, J.Li, and L. Cai, Appl. Surf. Sci., 255, 6686 (2009).

82. E. A. Araújo, N. J. de Andrade, L. H. M. da Silva, A. F. de Carvalho, C. A. de Sá Silva, and A. M. Ramos, Food Bioprocess Technol., 3, 321 (2010).

83. N. Fong, A. Simmons, and L. A. Poole-Warren, Acta Biomater., 6, 2554 (2010).

84. S. Noimark, C. W. Dunnill, M. Wilson, and I. P. Parkin, Chem. Soc. Rev., 38, 3435 (2009).

85. O. Öztürk, M. Sudagidan, and U. Türkan, J. Biomed. Mater. Res. A, 81a, 663 (2007).

86. F. Poncin-Epaillard, J. M. Herry, P. Marmey, G. Legeay, D. Debarnot, and M. N. Bellon-Fontaine, Mater. Sci. Eng. C, 33, 1152 (2013).

87. C. Sousa, D. Rodrigues, R. Oliveira, W. Song, J. F. Mano, and J. Azeredo, AMB Express, 1, 1 (2011).

88. Q. Huang, L. Lin, Y. Yang, R. Hu, E. A. Vogler, and C. Lin, Biomaterials, 33, 8213 (2012).

89. C. R. Crick, S. Ismail, J. Pratten, and I. P. Parkin, Thin Solid Films, 519, 3722 (2011). 